\title{
Raul Seixas e o Brasil pós-64: cultura, repressão, censura
}

Dílson César Devides. Mestrando em Letras (Estudos Literários) pela UFMS/CPTL. Professor de Teoria Literária na FATEB e Metodologia do Ensino de Literatura no UNISALESIANO). dcdevides@gmail.com

Resumo: O presente artigo tem por finalidade discutir as relações histórico-culturais d o Brasil ditatorial (pós-1964) e as composições de Raul Seixas. Num primeiro momento, é feito um rápido levantamento de fatos culturais importantes (Festivais, Cinema Novo, Tropicalismo, Literatura marginal) para depois, num segundo ensejo, abordá-los tratando mais diretamente da visão de Seixas acerca, principalmente, da censura e da repressão.

Palavras-chave: Raul Seixas; ditadura; censura; repressão; cultura.

A música popular passa a ser o espaço "nobre", onde se articulam, são avaliadas e interpretadas as contradições socioeconômicas e culturais do país, dando-nos por tanto seu mais fiel retrato.

Silviano Santiago

\section{Cultura em tempos de repressão}

Milagre econômico. Durante o governo Médici (1969-1974), o crescimento da Petrobrás (e de outras estatais, devido em parte pelo estímulo às exportações), da construção civil, o acesso mais fácil aos bens de consumo típicos da burguesia (carros, imóveis, eletrodomésticos), um maior cuidado em relação às questões do campo, e até mesmo o tri-campeonato mundial da seleção de futebol obtido no México, serviram para autopromover a administração, que fazendo uso dos meios de comunicação, vendiam a imagem de país forte e perseverante, pronto para ocupar o lugar que era seu por direito entre os desenvolvidos.

Não era outra coisa que esperava a população (e talvez até mesmo o governo), ludibriada por obras como a usina de Itaipu e a rodovia Transamazônica (esta última ainda hoje inconclusa). No entanto, os recursos financeiros necessários para tais empreitadas vieram do estrangeiro e aumentaram de modo considerável nossa dependência pecuniária dos países verdadeiramente desenvolvidos. Mas como o "bolo" não foi dividido tal qual prometera o então Ministro da Fazenda Delfim Neto, no fim do governo Médici a população se viu obrigada a enfrentar filas e escassez de produtos e a perceber, a duras penas, que o milagre era na verdade um conto do vigário e que o santo era de barro.

O Festival de Woodstock, de 1969, tornou-se ícone da contracultura e no campo cultural as relações com o exterior não eram menores, a guitarra elétrica vem rivalizar com o tradicionalíssimo violão, discute-se sexo mais abertamente, fuma-se, bebe-se, veste-se como os hippies, o inglês é usado até mesmo como meio de subversão. Tais atitudes insurretas são marcas da contestação da juventude daquela virada de década, que encontrou em passeatas com direito a distribuição de flores, em 
danças cheias de gingados efusivos, no uso de drogas (principalmente a maconha e o LSD), em manifestações nas universidades, na busca de religiões do Oriente, uma maneira de participar do momento político-cultural em que viviam. Nas palavras da professora Miriam Aldeman:

é um movimento eminentemente teatral e auto-consciente. Assim, utiliza a performance e o espetáculo como métodos de ação: em lugar de "planejar uma revolução futura", trata-se de viver a mudança na transgressão direta e cotidiana, o que significa parodiar tanto a sociedade quanto a si mesma. Apropria-se da cultura popular para burlar a sociedade, os valores burgueses e a si mesma. Mas com esse "radicalismo estético", que borra as fronteiras entre a alta cultura e a cultura popular e vê a realidade como um teatro onde "sempre se está representando" [...]. [i]

É por esta época que "propondo uma música e uma letra agressiva contra o sistema, Seixas chega a importar para o Brasil o movimento 'sociedade alternativa', que nos Estados Unidos era uma proposta contrária aos valores da ideologia dominante"[ii]. Hoje, tal postura, não só já não causa espanto, como foi incorporada às diversas formas de manifestação (moda e toda sorte de bens consumíveis), e concebeu uma geração de pais extravagantes e filhos, por vezes, ponderados.

Parece indiscutível que são heranças da contracultura, na maneira em que estão hoje organizados, os movimentos de luta pela igualdade de direitos para as mulheres e em defesa dos homossexuais. Os movimentos anti-racistas e pela legalização das drogas. São também filhos da contracultura os movimentos pacifistas e as coloridas e "performáticas" passeatas contra a guerra e pelo equilíbrio ecológico. [iii]

É preciso, então, entender que toda ação que questione a ordem posta pode ser considerada contracultura, o que nos daria ainda mais um exemplo na atual: 0 movimento Hip Hop, que com sua indumentária própria, vocabulário particular e, inclusive, subdivisões artísticas, espanta e causa incompreensão por parte da sociedade conservadora e preconceituosa. Devemos, pois, ver as expressões dos anos 60 e 70 como fato social acabado, que receberam a alcunha de Contracultura, porém que não encerra o conceito filosófico e, por conseguinte, abstrato que abrange outras formas de contrair o que vige.

[...] É que nada é subversivo num sentido absoluto. [...]pois, que o subversivo é sempre relativo, contextual e - ainda mais na sociedade capitalista contemporânea - sempre susceptível à cooptação (pela "democracia do mercado", pela "mídia", ou pelas mesmas instituições da "política oficial"). [...] Talvez nesse sentido, a grande lição da contracultura esteja no reconhecimento que o subversivo tem que ser sempre re-inventado, para cada momento e cada lugar. [iv]

Teríamos, então, por todo o sempre manifestações de contracultura.

Ao falarmos dos anos 60/70 é impossível não lembrar que "é a época dos festivais, onde floresce a melhor poesia cantada - como as de Torquato Neto, Capinam, 
Gilberto Gil, Caetano Veloso." [V] Vem à mente, então, os famosos Festivais de Música Popular Brasileira da TV RECORD. É preciso, no entanto, dizer que tais eventos começaram na extinta TV EXCELSIOR em abril de 1965 e teve como vencedora a música Arrastão, de Edu Lobo e Vinícius de Moraes, interpretada por Elis Regina. Apenas em 1966 a TV RECORD lança seu festival, que já recebeu o ordinal segundo[vi], e concedeu a premiação máxima às composições $A$ Banda, de Chico Buarque, e Disparada, de Geraldo Vandré e Théo de Barros; naquele ano, Porta-Estandarte, de Geraldo Vandré e Fernando Lona, foi a campeã pela EXCELSIOR.

Poesia e música se misturavam nos palcos: "parece dar-se a ascendência da poesia sobre o romance, passando aquela a ser gravada em discos, e chegando assim com maior impacto junto ao público." "viil As platéias que participavam ativamente cantando e gritando os nomes de seus favoritos davam aos festivais a aura de megaevento bem ao gosto da sociedade de consumo que se fortalecia. Ser participante e, principalmente, vencedor de um festival era, não só uma excelente porta para o sucesso, como também o sonho de muitos jovens intelectuais da época que hoje se consagraram para além da música, como Chico Buarque, Caetano Veloso, Gilberto Gil e Raul Seixas para ficar em apenas quatro ícones. Nos trabalhos destes compositores não é difícil perceber que "textos musicais populares [...] demonstram sua relação com a série literária através da apropriação criativa de textos e temas da literatura e através da alusão, ou recriação de, momentos literários." [viii]

Em 1968 as coisas já não iam tão bem, os censores passam a interferir mais no processo criativo dos compositores sugerindo alterações, até que em dezembro daquele ano o governo militar, não contente com a censura imposta em 1964 pelo então presidente Castelo Branco (que criou o SNI - Serviço Nacional de Investigação), decreta o Ato institucional no 5 e a atenção volta-se com mais vigor às manifestações culturais.

Não que antes não se preocupasse, mas, tendo controlado a oposição política e os ataques mais diretos da impressa, a cultura tornara-se um espaço para onde haviam migrado as poucas formas de resistência, até pelas lacunas deixadas pelos censores. $\frac{[\mathrm{ix}]}{\mathrm{a}}$

Os festivais não resistiram por muito mais tempo, e em 1969 o último evento da TV RECORD consagrou Sinal Fechado, de Paulinho da Viola; já na TV GLOBO o último prêmio foi dado a Fio Maravilha, de Jorge Bem, em 1972. Neste mesmo ano e evento Raul Seixas (ainda produtor da CBS) inscreveu dois trabalhos: Let Me Sing, Let Me Sing, defendida por ele próprio, e Eu sou eu, Nicuri é o Diabo, interpretada por Lena Rios e os Lobos. Houve, em anos posteriores, a tentativa de se retomar os festivais, mas, como disse Ana Maria Bahiana, "a censura e a repressão direta, com prisões e exílios, tiraram dos festivais sua função de ponto de encontro e reduziram-nos apenas a feiras para novas contratações." $[\mathrm{x}]$

A música tornou-se um dos alvos preferenciais da censura e da repressão, fato que gerou uma saída (nem sempre por vontade própria) de intelectuais brasileiros 
do país, e os que ficaram tiveram que recorrer a subterfúgios cada vez mais engenhosos para burlar os militares ou entregaram-se a obras de consumo fácil e préstimo duvidoso, "atemorizados pela situação vigente, não apenas os autores mas também os produtores e editores começaram a praticar a autocensura."[xi] Até mesmo Chico Buarque, um dos mais ativos, combativos e produtivos intelectuais brasileiros, afirma em entrevista no ano de 1971: "é claro que cheguei à autocensura." [xiil Alguns artistas chegaram, até, a criar autores fictícios para poder publicarem seus trabalhos. Há quem, inclusive, acredite que a pressão era tão grande sobre os artistas que os músicos, dramaturgos, escritores e toda sorte de produtores de cultura dos anos 70 foram, de alguma forma, infectada pela autocensura:

Nos anos 70, não havia clima para criação artística e, mesmo quando estatisticamente os problemas com a censura se reduziram, seus efeitos sobre toda uma nova geração de criadores permaneceram irreversíveis. Podados em suas primeiras investidas, estes jovens fatalmente se enquadram na autocensura. $\underline{\text { Xiii] }}$

Muito embora, seja um fato possível, creio que seja difícil generalizar tal postura, a menos que seja declarada (com o fez Chico Buarque). No que diz respeito a Raul Seixas, não conheço registro em que afirme que se autocensurava, o que não implica dizer que fazia seu trabalho alheio à censura, mas utilizava vários recursos para poder passar sua mensagem.

A censura se apresentava, assim, sob dois ângulos ou faces. Uma, repressiva, que diz não, e outra, disciplinadora, que incentiva uma certa orientação. Dessa forma, a censura do período militar se define menos pelo veto e mais pela repressão seletiva. Censuram-se livros, mas não a indústria cultural; peças teatrais, mas não o teatro; filmes, mas não o cinema; músicas, mas não a indústria fonográfica.. xiv]

Apesar de extensa, a citação de Vilarino resume bem a repressão durante o período em questão. Mesmo vetando muitas obras, o governo foi grande mecenas das artes (evidentemente daquela arte que o interessava), o que não impediu que muito fosse jogado no fundo de gavetas e lá permanecesse até que o regime militar acabasse. Para exemplificar basta dizer que foi preciso esperar oito anos para que Apesar de Você, de Chico Buarque, fosse liberada em 1978 com a revogação do Al-5; e que Raul Seixas, depois de ter seu apartamento invadido, revistado e revirado pelos militares que buscavam indícios de uma falada sociedade alternativa, foi expulso do país em 1974 (durante este período viveu nos Estados Unidos e pôde conhecer lugares importantes para o rock mundial, como por exemplo, Memphis, terra natal de Elvis Presley); e em sua última entrevista para a televisão concedida a Jô Soares, revela: "eu sempre tive problemas com a censura. Até hoje eu tenho 11 músicas censuradas. Eles olham minha obra de cima para baixo. Sacodem para ver se sai alguma coisa." [xv] Este testemunho data de 1989, ano da morte do compositor baiano, quatro anos após o fim da ditadura, dez depois do fim do Al-5.

Faz-se necessário, ainda, salientar que nem tudo era perspicácia e engenho 
no período, não podemos ignorar que a Jovem Guarda atenta aos anseios de uma classe média descomprometida e preocupada com vendagem, produzia músicas, na sua maioria, alienadas, "principalmente após o golpe militar de 64, período em que a participação político-social caracterizava as artes em geral e a música em particular, a Jovem Guarda foimais um movimento um tanto conformista e menos transgressor."[xvil A Bossa Nova, por sua vez, se teve por um lado uma incrível riqueza musical, no que se refere à arranjos e acordes, por outro teve letras que cansavam com suas paisagens praianas com barquinhos, céu azul e sol. $O$ fato é que “[...] começou-se a ouvir um tipo de música mais agressiva, rústica e um tanto cansada de tanto azul-praia-amor, que caracterizara as canções burguesas da Bossa Nova." [xvii]

Vilarino diria ainda que

talvez o que melhor tenha caracterizado os festivais de música na década de 60, seja essa maneira engenhosa, porque bem elaborada, de dizer algo. Nos festivais não se cantava apenas, dizia-se. A música e a poesia embutidas reforçavam uma voz. $\frac{\text { [xviii] }}{}$

E tal voz falou mais alto e marcou época com o Tropicalismo, com o Cinema Novo, que mantinham uma relação bastante estreita devido a admiração de Caetano Veloso pelo cineasta Glauber Rocha, e com o teatro. “[...] num certo momento, o teatro, o cinema, a literatura e a música se cruzaram, movidos por interesses ideológicos e estéticos. Alimentaram-se mutuamente dentro de um mesmo projeto social e socializante."[xix]

A s referências aos primeiros modernistas são claras e declaradas no Tropicalismo, Caetano via em Oswald de Andrade o supra-sumo da arte brasileira e encontrou em Rocha uma boa referência no cinema. "Toda aquela coisa de Tropicália se formulou dentro de mim no dia em que vi Terra em Transe". ${ }^{[x x]}$ Quando percebemos em letras tropicalistas uma mistura de imagens que vão dos grandes centros ao interior, das praias badaladas ao árido sertão, há aí uma influência do Cinema Novo, da estética da fome, da tentativa de mostrar através da fragmentação de imagens, de textos, de idéias, a dura realidade brasileira e, como era o intuito de Rocha, de toda a América Latina que mesmo tendo características tão diversas guarda uma relação visceral.

O cinema popular, que trazia o samba e o morro como recursos de construção nacional, apresentava como projeto a integração entre a música e o cinema, ou a nação era alegorizada pela representação que - cinema dela fazia, ao construir uma terceira imagem pela justaposição de tomadas cinematográficas e musicais [...] [xxi]

"Deus e o Diabo na terra do Sol", "Toda nudez será castigada", "Macunaíma", representam toda essa miscelânea de informações e representações que, na visão dos cineastas e dos tropicalistas, são o Brasil e a América luso-espanhola. [xxii]

Em uma passagem interessante de "As aventuras de Raul Seixas na cidade de 
Thor" [xxiii] lemos:

$[\ldots]$

Acredite que eu não tenho nada a ver

Com a linha evolutiva Música Popular Brasileira

A única linha que eu conheço

É a linha de empinar uma bandeira

$[\ldots]$

Por estas palavras é possível perceber que Seixas não aceitaria rótulos que o comparasse ou aproximasse aos tropicalistas. Nestes versos encontra-se a afirmação, por parte do compositor, de que ele não se enquadra na estética de Caetano e Gil, que para alguns estudiosos se pautaria, principalmente, na "insubordinação de valores, a ruptura com a linguagem institucionalizada e a interrupção do discurso míticonacionalista [...]." [xxiv] Dentre estes itens, poderia dizer que apenas quanto a linguagem, Seixas estaria cerca dos tropicalistas, e mesmo assim, de modo distinto, pois a linguagem do roqueiro é mais popular e, ao que me parece, nada alicerçada nos preceitos antropofágicos de Oswald de Andrade.

Pelos lados das artes dramáticas os CPCs $[\mathrm{xxV}]$ (Centros Populares de Cultura, criados durante o governo João Goulart), com Ferreira Gullar entre outros, davam fôlego e incentivam peças e criações e companhias de teatro. Mas para calar os alaridos da dramaturgia, os militares acabaram com os centros, não sem antes ter deixado nascer os grupos Arena e Opinião (responsável pela estréia de $O$ Rei da vela, peça de Oswald de Andrade), e ter despontado Augusto Boal, José Celso Martinez e Guarnieri.

Na literatura, para a qual devemos olhar tendo em mente os escritos de Linda Hutcheon, Andreas Huyssen, Silviano Santiago e Eneida Maria de Souza, para ficar apenas em alguns expoentes que nos dizem que já não há fronteiras entre as altas literaturas e a cultura de massa, pois "devemos abandonar a distinção eruditopopular"[xxvi] e passarmos a tratar do assunto de modo horizontal, já que a verticalidade não se aplica mais. Isso porque “o pós-modernismo é, ao mesmo tempo, acadêmico e popular, elitista e acessível." [xxvii] E já não se cogita mais onde estão as margens, uma vez que não há mais centro definido, e o local e o global fundem-se, na feliz expressão de Canclini, em glocal[xxviii]. "O local e o regional são enfatizados diante de uma cultura de massa e de uma espécie de aldeia global de informações [...]. A cultura (com $C$ maiúsculo, e no singular) se transformou em culturas (com $C$ minúsculo, e no plural) [...]". [xxix] Estas relações tornam-se mais visíveis quando observamos fatos como a estrondosa vendagem dos livros de Paulo Coelho. Adorado pelo público, repudiado por boa parte da crítica, faz parte da Academia Brasileira de Letras e é reverenciado em diversos países mundo afora. Seu sucesso serve de exemplo para que não viremos as costas ao que parece populesco ou popular; deve, isto sim, servir de estímulo para que busquemos aparatos teóricos que nos permitam compreender o porquê do êxito de um autor que, para muitos, escreve livros de auto- 
ajuda e tem uma narrativa repleta de lugares-comuns. Será que não é justamente isso que quer o leitor atual, um texto que se aproxime de sua realidade e retrate suas angustias e apreensões? Parece-me que há uma certa falta de vontade em aceitar o fato de que hoje autores como Visconde de Taunay, Bocage e Murilo Rubião não façam parte do gosto de leitores mais jovens; parece-me, ainda, que se recusam a concordar (ou esquecem) que sempre que houve, no universo artístico, uma mudança que trouxesse consigo um novo período (como as escolas literárias), os novos artistas eram considerados de menor valor. Assim foi com Augusto dos Anjos, Mário de Andrade, Júlio Ribeiro, considerados, hodiernamente, grandes autores e pensadores brasileiros, por que com Paulo Coelho, com os cantores de Rap, com os grafiteiros, seria diferente?

Bem, na literatura da época tínhamos os consagrados Clarice Lispector, João Cabral de Melo Neto, João Guimarães Rosa, Dalton Trevisan e os que despontavam ou s e firmavam como Rubem Fonseca, João Ubaldo Ribeiro, Nélida Piñon, Moacyr Scliar, João Gilberto Noll, Ignácio de Loyola Brandão e outros. No entanto, o que marcaria as letras dos 60/70 seria a chamada literatura marginal. $[x x x]$ o termo marginal se deve principalmente ao fato de o material usado para confeccionar as obras, o meio de distribuição (em portas de universidades, teatros, eventos, muitas das vezes feita pelo próprio autor, isso para não dizer que por vezes os textos, comumente poemas, eram afixados em muros e postes), a diagramação em formato de cartas ou cartazes dentro de envelopes, a impressão mimeografada, estarem à margem da sociedade convencional (inclui-se aqui os produtores, dispersores e consumidores de cultura).

De um modo geral, estes novos produtos literários tinham um forte caráter artesanal e lúdico; especialmente naqueles textos mais discursivos - o que, por sua vez, se combina com um certo desprezo em relação ao prestígio acadêmico, intelectual, bem como aos padrões consagrados de 'qualidade' e 'bom gosto'. [xxxil

Se pensarmos em Raul Seixas, não fica complicado encontrar exemplo em que os padrões são ridicularizados e a condição de intelectual acadêmico é avacalhada. Tal característica ocorre ao longo de toda sua obra, em "Eu também vou reclamar", de seu quinto disco, $H$ ádez mil anos atrás, a quinta estrofe diminui o valor da intelectualidade:

Olho os livros na minha estante

Que nada dizem de importante

Servem só pra quem não sabe ler[xxxii]

É evidente que não se está pregando que os livros tenham pouca serventia, mas se questiona o modo como são lidos, sem reflexão e com alienação, quando deveriam servir para o raciocínio que levasse a uma (ainda que pretensa) autonomia intelectual.

Em Rock'n'roll, de seu último disco, difama a sociedade baiana, retrógrada e conservadora, que acredita que a intelectualidade está na universidade, em espetáculos teatrais; ignorando a riqueza cultural que compõe a Bahia (e evidentemente o Brasil) como as raízes africanas presentes no Candomblé, na culinária, enfim, no modo baiano 
de ser.

No teatro Vila Velha, velho conceito de moral

Bosta nova pra universitário, gente

Fina, intelectual

Oxalá, oxum dendê Oxossi de não

Sei o quêt $[x x x$ iii]

Por outro lado, é possível perceber que em suas composições há um amálgama entre erudito e popular. Tal hibridização (elemento bastante contemporâneo, diga-se de passagem) garantiu ao compositor conquistar um público bastante amplo (desde universitários a empresários) e comprovaria o que disse Huyssen de que "o erudito se torna tabu e o popular norma.." [xxxiv] É, pois, com sua linguagem simples e ao alcance de todos que Seixas faz suas bricolagens culturais, como, por exemplo, em "Rock do Diabo", onde coloca lado-a-lado o diabo (figura que habita o imaginário de grande parte da população mundial, principalmente da mais carente) e Freud, um dos maiores pensadores da História; o refrão traz:

Enquanto Freud explica as coisas

O diabo fica dando os toques. $[\mathrm{xxxv]}$

Nessa passagem, mesmo mostrando certa erudição ao citar o pai da psicanálise, tal ocorrência se dá em tom de galhofa, como se dissesse que após as teorias freudianas não há mais segredos na alma humana e que toda e qualquer pessoa poderia conhecer-se e ao próximo fazendo análise. Isso não elimina a figura tártara do diabo que aparece como aquele palpiteiro ou intrometido na conversa alheia que serve para mostrar que cada ser tem sua opinião e que ela deve ser respeitada, sendo, pois, muito difícil que alguém além do próprio ser sabia o que se está passando.

Retomando a literatura propriamente dita, esta nos trouxe à tona Paulo Leminski (a princípio bastante ligado ao grupo concretista), Ana Cristina Cesar, Cacaso, Chacal, Chico Alvim.

Desta produção destaca-se os relatos memorialistas que tratavam, basicamente, da vida no exílio, a poesia em tom confessional, que se utiliza de fatos corriqueiros para lançar um lirismo por vezes angustiante. Messeder Pereira quando trata da obra de João Carlos e do grupo Frenes [Xxxxvi] comenta que "esta presença do lirismo (ao lado do cotidiano) marcaria não apenas os textos destes autores especificamente, mas caracterizaria boa parte da produção poética desta década." [xxxvii] o cotidiano em Raul Seixas é tão freqüente que chega a constituir-se regra (por vezes próximo do non sense), difícil é encontrar composições suas nas quais o dia-a-dia de qualquer pessoa ganha destaque para ilustrar, metaforizar diversas situações. Super-heróis (do disco Gita - 1974) e É fim do mês (de Novo Aeon - 1975) para ficar em apenas dois exemplos. A primeira conta um simples passeio de fim de tarde no qual algumas celebridades (ou seus sósias) estão pelas ruas, uma diversão barata e singela na qual o próprio Seixas se vê imitado:

Então eu disse a Dom Paulete: eu conheço aquele ali

Não é possível, Dom Raulzito 
Quem é que no Brasil não reconhece o grande trunfo do xadrez

Saí pela tangente disfarçando uma possível timidez $[\mathrm{xx}$ x viii]

A saída tangencial é bastante propícia para a época, em que não era conveniente tirar satisfação por pouca coisa (ou coisa alguma!) sob risco de sérias repressões militares. O melhor a fazer era passar por ignorante e seguir, mesmo que isso demandasse suprimir desejos e direitos.

A crítica à alienação do povo não poderia faltar: Como é que eu posso ler se não consigo concentrar minha atenção/ Se o que me preocupa no banheiro ou no trabalho é a seleção. Qualquer referência à propaganda do governo Médici que, se aproveitando do tri-campeonato de futebol conquistado no México em 1970, alardeava a imagem de um país forte e que, já tendo conquistado o topo do mundo no futebol, também o alcançaria em todas as demais áreas, não é mera coincidência.

A segunda letra, por sua vez, é ainda mais familiar à maioria dos brasileiros. Trata da dificuldade de se adquirir os bens necessários para a sobrevivência satirizando as condições para conseguir, por exemplo, a primeira e a última morada:

Eu já paguei a luz, o gás, o apartamento

Kitnete de um quarto que eu comprei a prestação

Pela Caixa Federal, au, au, au

Eu não sou cachorro não, não, não

[...]

Tô terminando a prestação do meu buraco

Meu lugar no cemitério pra não me preocupar

De não mais ter onde morrer

Ainda bem que no mês que vem

Posso morrer, já tenho o meu tumbão, o meu tumbão[xxxix]

Segue criticando os impostos (sempre altos!), o servilismo que impede a tomada de atitudes sob pena de represália (a perda do emprego, por exemplo), e, principalmente, a passividade de boa parte da população que nada faz para reverter a situação e apenas sabe reclamar:

Como é que você vive alegremente, acomodado

E conformado de pagar tudo calado

Ser bancário ou empregado, sem jamais se aborrecer

Ele só quer, só pensa em adaptar.

Este teor burlesco é o mínimo que se poderia esperar de alguém que vê em Luiz Gonzaga e Elvis Presley “[...] o mesmo tom safado, irônico. Acho que o humor de nosso nordestino é muito parecido com o humor do americano do Sul, onde nasceu o rock'n'roll'. [xl]

Deste apelo ao cotidiano, ao popular, ao corriqueiro, Sartre diria:

Se a sociedade se vê, e sobretudo se ela se vê vista, ocorre, por esse fato mesmo, a contestação dos valores estabelecidos e do regime: o escritor lhe apresenta a sua imagem e a intima a assumi-la ou então a transformar-se. $\underline{\text { xli] }}$

É esta atitude que buscavam os artistas da época. Não admitiam a 
passividade e pretendiam, dentro das brechas que a censura deixava e do que os recursos lingüísticos oferecem, trazer um pouco de conscientização à massa trabalhadora alienada e oprimida em prol do crescimento nacional. A respeito disso o professor José Miguel Wisnik diz:

Foi-se formando uma linguagem capaz de cantar o amor, de surpreender o quotidiano em flagrantes lírico-irônicos, de celebrar o trabalho coletivo ou de fugir à sua imposição, de portar a embriaguez a dança, de jogar com as palavras em lúdicas configurações sem sentido, e de carnavalizar na maior (subvertendo-a em paródia) a imagem dos poderosos. $\underline{\text { xliii }}$

O mesmo autor diz que à época dos 70 a música se dava ou pelo modo industrial, ligada à gravadoras (que cresciam e ganhavam força) e aos demais meios de propagação, principalmente a televisão e o rádio, ou de modo "artesanal, que compreende os poetas-músicos criadores de uma obra marcadamente individualizada, onde a subjetividade se expressa lírica, satírica, épica e parodicamente."[xliii] Apesar de sabido que Seixas estava inserido no universo empresarial da música como produtor de uma gravadora, é nesta segunda classificação (a que traz mais forte a marca de elaboração poética) que, acredito, enquadra-se. E é este labor de "poeta-músico" que se encontra quando Seixas trata da religiosidade, de questões sobre o mercado cultural e, evidentemente, faz uso para burlar a censura e a repressão, como o que se verá na próxima etapa deste trabalho.

\section{Alfândega da censura $[\mathrm{Xliv}]$}

Em um trabalho que trata do Brasil pós-64 não poderia faltar uma explanação mais direta das composições de Seixas acerca da ditadura e da censura. Numa época e m que "a cultura era considerada supérfluo e o músico popular tido como um marginal, um elemento de alta periculosidade" [xlv], Seixas não se intimidou e mandou seus recados. Dentre várias referências feitas ao momento militar dos anos 1970 (principalmente), dirimi tratar daquelas letras que são mais claramente diretas, mesmo que sempre cifradas; são elas: A mosca; Rockixe; Sociedade alternativa; As aventuras de Raul Seixas na cidade de Thor; Paranóia[xIvil]; Sapato 36; Conserve seu medo; Abrete sésamo; Anos 80; Metrô linha 743. Sem a pretensão de reunir tudo o que Seixas tenha produzido sobre o assunto, acredito que se possa ter uma boa noção de suas idéias, pensamentos e, principalmente, o modo de ver este momento histórico, uma vez que são canções que vão de 1973 a 1984.

Krig-ha,bandolo!, disco de 1973, o primeiro da carreira solo de Seixas, "foi um daqueles discos antológicos, em que o artista joga tudo o que amadureceu durante anos a fio." [xlviil A faixa que abre a obra (depois de uma introdução na qual canta Good rockin' tonight aos nove anos) é a famosíssima $A$ mosca [xlviii]. Nesta letra, embalado por sons de atabaques e berimbaus, deixa evidente que, já que sempre "há 
uma pedra no meio do caminho" [xlix], Seixas será aquele inseto indesejado que estraga o agradável jantar e causa asco (para não dizer antipatia ou aversão). Começa assim um jogo dialético com os militares que são para ele o verdadeiro obstáculo. No tom debochado que se tornaria característica marcante, Seixas provoca e dá o aviso:

Eu sou a mosca que pousou em sua sopa

Eu sou a mosca que pintou pra lhe abusar

Eu sou a mosca que perturba o seu sono

Eu sou a mosca no seu quarto a zumbizar

E não adianta vim me detetizar

Pois nem o D.D.T. pode assim me exterminar

Porque você mata um e vem outro em meu lugar

Atenção eu sou a mosca

A grande mosca

[...]

Observando e abuzando

$[.$.

Cinco anos depois do Al-5, último ano de mandato de Médici, o país crescia e a inflação também (mais de $15 \%$ ), a repressão continua forte, e talvez por estar despontando como pensador, Seixas se achasse no direito de dar seu cartão de visitas e o fez. Antes não o fizera. Em tempos em que "a arte abandona o palco privilegiado do livro para se dar no cotidiano da Vida" $[1]$, tornou-se um dos alvos preferenciais dos censores, o que mostra que conseguiu ser uma "mosca" realmente perturbadora e que, de fato, não adiantou querer detetizá-lo (o D.D.T. poderia muito bem ser substituído por SNI[li] ou DOPS[lii]) expulsando-o do país no ano seguinte, pois outros continuaram a azucrinar a vida dos militares e mesmo de fora estaria observando o que se passava no Brasil.

Em outra composição do mesmo álbum, Rockixe[liii], a mensagem de que o incômodo acontecerá se repete, no entanto, desta vez mostra-se preocupado com o que possa acontecer:

Eu tinha medo do seu medo do que eu faço

Medo de cair no laço que você preparou

Eu tinha medo de ter que dormir mais cedo

Numa cama que eu não gosto só porque você mandou...

O fato de ter medo do medo do outro, se explica pelo motivo de que sabe que não é bem visto e que aborrece com o que faz e, por isso, representa algum tipo de ameaça, até porque não nos importamos com o que não nos importuna. Sabe ainda que a qualquer momento pode ser preso (cair no laço) e assim ser impedido de agir livremente. Ainda que reconheça a força do oponente, debocha dela (típico de Seixas) dizendo que é mais belo (Você é forte mais eu sou muito mais lindo), o que permite ver aí um discurso avaliativo claro, ou seja, a situação vigente é feia. E critica a situação econômica dizendo: Na esquina da falência que eu te pego pelo pé. Provavelmente, já 
imaginando o fracasso do milagre econômico. Quando avisa: Eu vim de longe, vim duma metamorfose (talvez a mosca da canção anterior) evidencia o seu poder de adaptação e desafia:

Você é forte, faz o que deseja e quer

Mas se assusta com o que eu faço, isso eu já posso ver

E foi com isso, justamente, que eu vi

Maravilhoso, eu aprendi que eu sou mais forte que você

Entra assim numa verdadeira luta de Davi contra Golias, tornando-se alvo preferencial da censura, o vencedor deste embate foi a cultura, que pôde presenciar uma figura tão ativa combatendo, pelas palavras, atitudes com as quais não concordava. O resultado são as letras aqui presentes e outras que por um motivo de delimitação temática não aparecem neste trabalho.

No ano em que Ernesto Geisel "vence", no Colégio Eleitoral, o oposicionista Ulisses Guimarães e que sai da circunspeção política o deputado Tancredo Neves (duas importantes figuras para a retomada da democracia nos anos 80), com a inflação galopando $(34,5 \%)$ e com crescimento interno menor que o do ano anterior $(8,2 \%$ ante $14 \%$ de 73$)^{[\text {liv] }}$, Seixas lança Gita, que “mostrou Raul dividido entre a crítica social e o escapismo místico que tomava conta dos desiludidos 'bicho-grilos' (sic)"[lv]. No que se refere às composições de teor crítico, são bons exemplos as letras de As aventuras de Raul Seixas na cidade de Thor[lvi] e Sociedade alternativa. Na primeira, Seixas fala do destemperamento dos governantes e não suaviza as palavras para nomeá-los:

Tá rebocado meu compadre

Como os donos do mundo piraram

Eles já são carrascos e vítimas

Do próprio mecanismo que criaram

Carrascos, donos do mundo, são expressões que comprovam a idéia de que Seixas via o regime militar como algo desumano, que atenta contra o que ele mais prezava: a liberdade. E o que é pior, mostra o despreparo em administrar a situação que eles mesmos criaram (ou será que é necessário usar da força quando se está seguro do que está fazendo e que tais atitudes são para o bem da população?). O uso de força fica evidente quando diz que "A arapuca está armada" e segue em uma comparação bem zombeteira:

Buliram muito com o planeta

E o planeta como um cachorro eu vejo

Se ele não agüenta mais as pulgas

Se livra delas num sacolejo

O cachorro pode ser o regime militar, as pulgas, todos aqueles que não concordem com a censura, a repressão. A alternativa: livrar-se dos que atrapalham. É interessante o uso do verbo livrar, em época de escassa liberdade, ele é usado em seu sentido menos adequado (se assim posso dizer), o de acabar, aniquilar, destruir, e não raras vezes, matar os discordantes. A canção segue e trata de questões outras que não especificamente do regime, mas por ele influenciado. Questiona o posicionamento de 
alguns rebeldes que se perderam ou deixaram-se perder (Hoje a gente já não sabe/ De que lado tão certos cabeludos/ Tipo estereotipado/Se é da direita ou da traseira); diz da enxurrada de influências que chegavam ao país naquela época ( $E u$ já passei por todas as religiões/ Filosofias, políticas e lutas) e termina com mais tapa de pelica na faces dos militares que acreditavam ser o único caminho seguro para o Brasil: Aos 11 anos de idade eu já desconfiava/ Da verdade absoluta.

Quanto à segunda letra, digo apenas que é grito de insubmissão, de revolta, que tenta despertar quase que por imposição (muito embora este termo não seja adequado para tratar de Seixas) um sentimento de revolta ante a condição posta. Cantá-la é concordar com seu lema: Faze o que tu queres/ Pois é tudo da leillviil. É concordar que o que é imposto (agora sim o termo corretamente empregado) não deve ser aceito, pois apenas o que é feito por vontade própria é correto e verdadeiro, e como cada ser tem um jeito de ser, tudo é permitido.

Este álbum é todo em cima do Livro da Lei, que Aleister Crowley recebeu, ditado por um ser do Novo Aeon. Mas não é... apostólico. São simplesmente coisas que eu descobri e digo, porque tenho esses meios de dizer, porque meu trabalho é dizer, sacar, dizer. Sou o cientista que faz a granada que o soldado lança pra explodir tudo... Não levei Aleister Crowley totalmente a sério, não. Aliás, eu acho que é isso que ele queria. Tirei coisas dele para mim, aproveitei. $\frac{\text { [lviii] }}{2}$

Essas atitudes e pensamentos em 1974 são como um pedido de punição, e tal música não passou ilesa, sua execução, que insuflava o púbico, rendeu a Seixas uma visita dos militares a sua residência em busca de indícios da dita sociedade. $O$ compositor foi para os Estados Unidos para acalmar os ânimos de seus admiradores, dos censores e dele mesmo. ${ }^{[l i x]} \mathrm{Em}$ depoimentos posteriores à época, divergindo do excerto acima, Seixas diria sobre Gita:

É um disco doutrinário. Já reparou na capa? Estou eu lá, de dedo pra cima, veja se possível! Como se eu quisesse indicar caminhos para as pessoas. Mas é o retrato mesmo do que eu fui no passado. Eu estava pondo pra fora meu lado de Cristo, de Jesus, sabe como é, que adora sofrer pelas pessoas, mostrar o caminho às pessoas. Gita foi todo

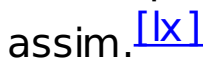

Já em 1975, o Brasil mantém negociações com a Alemanha entorno da energia nuclear; "começa o processo progressivo de resgate da liberdade de impressa" [Ixi], no entanto, morre o jornalista Vladimir Herzog, talvez para dizer que as coisas não serão tão fáceis; a inflação diminui, a taxa de crescimento também.Seixas volta para o Brasil e lança Novo Aeon, disco que considera menos doutrinário que o anterior (ele já era considerado guru por muitos jovens e esse fato o assustava, tinha medo de ser assinado por um fã). A respeito de Paranóia [lxii], Seixas disse:

Para Nóia. É como se fosse uma garota, porque é assim que eu vejo o medo. Fui um dia em que fiquei encucando toda a noite, e tive muito medo quando vi o dia nascendo. Terror mesmo. Aí decidi: ou eu luto com o medo ou ele me vence. Chamei os fantasmas todos pra brigar e 
daí saiu essa música. [xiii]

Destaco desta composição o seguinte fragmento:
$[\ldots]$
Se eu vejo um papel qualquer no chão
Tremo, corro e apanho pra esconder
Medo de ter sido uma anotação que eu fiz
Que não se possa ler
E eu gosto de escrever
Mas, eu sinto medo
$[\ldots]$

Fica clara a relação com a censura. O medo é tanto que até mesmo dentro de casa tem-se receio de que algo comprometedor possa chegar a mãos indevidas. E pior. Nem mesmo nos momentos mais íntimos se está sozinho, pelo contrário, é sempre vigiado por uma entidade demiúrgica:

Tinha tanto medo de sair da ama à noite pro banheiro

Medo de saber que não estava ali sozinho porque sempre

Sempre, sempre

Eu estava com Deus

[...]

Minha mãe me disse há tempo atrás

Onde você for, Deus vai atrás

Deus vê sempre tudo o que cê faz

[...]

Vacilava sempre a ficar nu lá no chuveiro, com vergonha

Com vergonha de saber que tinha alguém ali, comigo

Vendo fazer tudo o que se faz dentro dum banheiro

$[\ldots]$

De tão dramático chega a ser patético. O medo do desconhecido, daquilo que não se pode ver ou tocar, contra aquilo que não se pode lutar, toma conta de todo o ser a ponto de deixa-lo louco. E foi isso que a ditadura com seus censores conseguiram fazer: sumir com pessoas ativas, que não se calavam; coibir manifestações de reprovação contra o governo; impedir que artistas cantassem, escrevessem, encenassem, pintassem qualquer coisa que não fosse de acordo com o regime. Exemplo incontestável de como se davam as relações dos censores com os artista, nos dá Margarida Autran:

Quando o disco Banquete de mendigos, do qual constavam velhas composições como Oração de Mãe Menininha, de Dorival Caymmi, e Asa Branca, de Luiz Gonzaga, e cuja venda reverteria em benefício de instituições mantidas pelo ONU, é apreendido em todo território nacional (1975), o diretor do Departamento de Censura, Rogério Nunes, justifica: "As músicas do disco, interpretadas por vários autores, entre os quais Chico Buarque, Paulinho da Viola, Raul Seixas, Edu Lobo e Gal Costa, têm conotações políticas desfavoráveis ao governo." "[xiv]

É interessante notar que a impressão passada pela fala do diretor é de que o fato nocivo está nos intérpretes das músicas e não necessariamente nas próprias composições, uma vez que foram escritas já há algum tempo, mas como os cantores 
são pessoas já estigmatizadas pelo regime, qualquer coisa que façam é motivo para retaliações, ainda que seja por uma causa humanitária como a de ajudar instituições de amparo a necessitados.

1976 é o ano em que morre, num desastre de carro, Juscelino Kubitschek de Oliveira, "o governo decreta luto oficial de três dias [...]. É o primeiro político cassado a receber homenagem." [|xv] o governo insisti na versão de suicídio no caso Herzog. Geisel "afasta do comando do II Exército o general-de-exército Eduardo d'Ávila Melo em decorrências das torturas e das mortes no DOI-CODI de São Paulo." "lxvil Para a vaga escolhe alguém mais afeiçoado à abertura, o general Dilermando Gomes Monteiro. Em 1977, Geisel repete a atitude em prol da abertura quando "exonera sumariamente o ministro do Exército, general Sylvio Frota, pré-candidato da linha dura à Presidência da República." [|xviil Tal atitude avigora a candidatura de João Baptista Figueiredo ao principal cargo do país. É neste ano que é lançado o disco $O$ dia em que a Terra parou. Entre canções à beira da melancolia como Sim e outras no mais puro estilo impuro de Seixas, misturando ritmos, há Você, Tapanacara, Eu quero mesmo; chama a atenção, como não poderia ser diferente, as canções que contestam o cotidiano, as situações postas, como No fundo do quintal da escola e Sapato 36.

Muito embora se possa dizer que Sapato $36^{[\text {[xviii] }}$ trata de questões familiares, o que é perfeitamente aceitável, uma vez que a auto-afirmação de um filho muitas vezes gera conflitos por haver falta de compreensão entre as partes ou, e principalmente, por não haver respeito; é inevitável pensá-la como crítica à ditadura. Logo no início quando lemos: Eu calço é 37/ Meu pai me dá 36, já se observa a falta de liberdade de escolher o que bem entender, aqui metaforizada no sapato (há uma pedra em meu sapato, diz a expressão popular) que causa desconforto e impede que se vá mais longe, que se progrida. Na seqüência: Pai eu já tô crescidinho/ Pague prá ver, que eu aposto/ Vou escolher meu sapato/ $E$ andar do jeito que eu gosto/ $E$ andar do jeito que eu gosto; é o pedido de confiança (nem me atrevo a dizer de liberdade), que, após nove anos de Al-5 e treze de regime militar, já é o momento de poder-se caminhar sem que algo incomode, sem chateações, sem perseguições. Nos versos posteriores vem a indignação com a falta de consideração que a população sofre por parte dos governantes: Por que cargas d'águas/Você acha que tem o direito/ De afogar tudo aquilo que eu/ Sinto em meu peito; tão forte é o descaso (o que não implica dizer desatenção) que atingi até os sentimentos, os sonhos, os desejos, tudo sufocado e reprimido em prol do bem do Estado que sempre exigiu consideração e, como não a tinha de todos, partiu para a violência, a canção mostra o caminho tão simples e eficaz para que qualquer conflito seja extinto: Você só vai ter o respeito que quer/ Na realidade/ No dia em que você souber respeitar/A minha vontade. O fim desta pendenga se dá, como era de se esperar, com a resignação da parte mais fraca que, no entanto, mostra-se mais racional e prudente (ou sensata), mas a conformação não se processa totalmente, pois mesmo sem ter a concordância da outra parte, sai em busca de algo que atendesse melhor suas necessidades, é um clamor de liberdade: Pai já tô indo-me 
embora/ Quero partir sem brigar/ Pois eu já escolhi meu sapato/ Que não vai mais me apertar.

No ano seguinte, 1978, o ministro-chefe do SNI, general João Baptista Figueiredo, indicado por Geisel, é eleito, é também o último do atroz Al-5; surge, então, uma esperança de que, de fato, a democracia possa voltar, começando pela liberdade de expressão.Talvez duvidando disso, Seixas em “Conserve seu medo" "[xix], do álbum Mata Virgem, alerta:
Conserve seu medo
Mantenha ele aceso
Se você não teme
Se você não ama
Vai acabar cedo

Já aparece aí a advertência, não se deve acreditar (pelo menos não totalmente) que a revogação do Al-5 vai acabar com a repressão, é preciso estar cauteloso (Esteja atento/ Ao rumo da História/ Mantenha em segredo/ Mas mantenha viva/ Sua paranóia) e não se esquecer dos acontecimentos anteriores, uma vez que a História é cíclica, e mesmo que para as outras pessoas não pareça, é imprescindível estar atento. Não que seja preciso ficar parado à espera de que se confirmem as expectativas (boas ou ruins), pelo contrário, tem-se que seguir a vida da melhor maneira e com esperança em dias melhores, mas sempre com cuidado. Isso está sintetizado em: $E$ ande pra frente/ Olhando pro lado. Por mais que se quisesse melhorias e se acreditasse que elas viriam, é sempre bom duvidar dos fatos e saber, ou ao menos tentar, analisar a situação para não ser pego desprevenido.

O último ano da década de 70 começa com a posse de João Baptista Figueiredo com promessas de guiar o Brasil rumo à democracia, criação do Partido dos Trabalhadores, na economia volta Delfim Netto (que desde Costa e Silva e Médici já comandava a economia nacional), a inflação corre como uma motocicleta e chega a $77,2 \%$ enquanto o crescimento do PIB (a pé) é de 6,8\%[1xx], em agosto é promulgada a Lei de Anistia. Os anos 80 começam com atos terroristas, pluripartidarismo, dois anos a mais de governo para prefeitos e vereadores (as eleições ocorreriam em 1982 para todos os cargos: vereador, prefeito, governador, deputados, senadores - exceto presidente!), a inflação, animada com o desempenho de Nelson Piquet (seria campeão mundial de automobilismo em 81 e bicampeão e 82), pega um Fórmula 1 e dispara (110,2\%), o crescimento (de carroça) é de 9,2\% (muito embora este número seria hoje algo estrondoso e digno de comemoração).Talvez, animado com a virada de década, Seixas aparece com Abre-te sésamo, um disco aparentemente descomprometido, que traz o engraçado Rock da "Aranha" (tratando o homossexualismo, que foi considerado com o principal motivo de propagação da AIDS), a fúnebre $\dot{A}$ beira do pantanal, a filosófica $O$ conto do sábio chinês, a lírica Minha Viola (escrita por Raul Varella Seixas, pai de Raul), as impugnantes Abre-te sésamo e Anos 80.

De Abre-te sésamo[lxxi], poderia dizer que é uma canção de quem se prepara para uma virada de década sem muita esperança de melhoras e, talvez, pasmo por ver 
que pouca coisa mudou, é o que se lê nos primeiros versos: Lá vou eu de novo/ Um tanto assustado/ Com Ali-Baba e os quarenta ladrões/ Já não querem nada/ Com a pátria amada / E cada dia mais enchendo meus botões. Nos versos subseqüentes, é posta às claras a situação do povo brasileiro do início daquela década em que era necessário lutar contra a fome e a falta de recursos os mais elementares para a sobrevivência, pois o verdadeiro brasileiro é um forte e não desanima: Lá vou eu de novo, brasileiro, brasileiro nato/ Se eu não morro eu mato/ Essa desnutrição/ Minha teimosia brava de guerreiro/ É o que me faz o primeiro dessa procissão. No refrão é possível verificar a inconstância das coisas e das oportunidades que aparecem e somem tão rapidamente que passa a impressão de não existirem: Fecha a porta, abre a porta/ Abre-te sésamo/ Fecha a porta, abre a porta/ eu disse,/Abre-te sésamo. Termina amargurado mostrando que a bagunça é generalizada e que apenas os tolos acreditam que o país está crescendo e que crescerá junto com ele: $E$ vamos nós de novo/ Vamos na gangorra/ No meio da zorra desse/ desse vai e vem/ É tudo mentira/ Quem vai nessa, pira/ atrás do tesouro de Ali-bem-bem.

A leitura de Anos $80^{[\mathrm{lxxii]}}$ ajuda a completar a interpretação da letra anterior e vislumbrar as perspectivas de Seixas para tal década. É uma canção alegre na qual os tons irônicos e debochados estão fortemente presentes numa crítica ácida e, por que não, jocosa. De início já se tem o refrão:

Hey, anos 80

Charrete que perdeu o condutor

Hey, anos 80

Melancolia e promessas de amor

Melancolia e promessas de amor

O que pode se esperar de um decênio que começa sem quem o dirija (vale lembrar que o presidente Figueiredo, repetidas vezes, deixou claro que era mais soldado que político, e que em outras ocasiões, principalmente depois do infarto, mostrou-se desejoso do término de seu mandato) e que traz tristezas e promessas que provavelmente não serão cumpridas? Muito pouco. Ainda mais quando os comandantes veraneiam (deixando suas obrigações por fazer e muitas vezes fazendoas sem competência para tal) enquanto o povo trabalha sem nem ao menos se dar ao luxo de sonhar com férias e conforto, é o que se encontra a seguir:

É o juiz das 12 varas de caniço e samburá dando atestado que o compositor errou

Gente afirmando não querendo afirmar nada, que o cantor cantou errado e que a censura concordou

Gente afirmando não querendo afirmar nada, que o cantor cantou errado e que a censura concordou

Mais adiante evidencia que a igualdade que tanto se queria existe sim, quando pensamos que a miséria está tanto entre os ricos (seja ela moral, seja as favelas que rodeiam os bairros nobres do Rio de Janeiro) e os pobres que sentem na pele os reflexos diretos das ações governamentais, mas tanto um quanto outro colaboram 
para que as coisas não mudem pois encobrem as falcatruas na expectativa de levar alguma vantagem, de obter algum favor: Pobre país carregador dessa miséria dividida entre Ipanema e a empregada do patrão/ Varrendo lixo pra debaixo do tapete que é supostamente persa pra alegria do ladrão/Varrendo lixo pra debaixo do tapete que é supostamente persa pra alegria do ladrão. Termina, então, ainda no início do percurso, derrotado em seus propósitos: Eu disse: hey, anos 80/Minha esperança... sonho de um sonhador!

Nos anos subseqüentes há o atentado do Riocentro, fato que dividiu o governo, o infarto de presidente Figueiredo (para muitos após este incidente o presidente nunca mais seria o mesmo), nas eleições de 82 a oposição conquista o governo dos maiores estados do país (Montoro em São Paulo, Brizola no Rio de Janeiro, Tancredo em Minas Gerias), o crescimento é de 0,8\%[lxxiii]. Em 83, com a inflação na estratosfera (211\%) [xxiv], começa a circular uma expressão que entraria para sempre na História nacional: Diretas-já. 0 ano de 84 é marcado por manifestações gigantescas (algumas com números próximos a meio milhão de pessoas), no entanto as eleições diretas não são aprovadas. Em meio a atitudes continuístas que cogitavam mais dois anos de governo para Figueiredo a fim de haver eleições diretas já em 86 (um grande interessado era Leonel Brizola, que desta forma poderia terminar seu mandato de governador dos cariocas e candidatar-se com chances de vitória), é lançada a candidatura de Tancredo Neves para presidente, e José Sarney para vice, que enfrentariam no Colégio Eleitoral Paulo Salim Maluf, escolhido pelo PDS. Mesmo com insinuações de que a vitória da chapa Neves-Sarney representaria uma ameaça comunista, eles vencem e assumem o país com uma inflação de $223,9 \%$ [lxxv], ou melhor, Sarney assume. Momentos antes do dia da posse Tancredo Neves tem problemas de saúde e necessita cuidados, porém, com receio de que Figueiredo não passasse a faixa a Sarney, adia os tratamentos até que, mesmo depois de várias cirurgias realizadas no Instituto do Coração, em São Paulo, falece no dia 21 de abril de 1985 e Sarney, que havia assumido a precedência (Figueiredo, realmente, não lhe passou a faixa), é efetivado no cargo.

É em meio a este painel que chega às lojas (em 1984) o disco Metrô linha 743, cuja faixa homônima, em uma narrativa agradável, resume bastante bem todo o período militar no que se refere, principalmente, à censura e à repressão. Começa já em ambiente hostil e típico de filme policial: Ele ia andando pela rua meio apressado/ Ele sabia que tava sendo vigiado[Ixxvi]; a pressa é característica de quem não pode perder tempo, neste caso, de alguém que sabe que não durará muito pelas ruas, pois é perseguido (ou acredita ser, tamanha a dureza das histórias que repercutem durante períodos de autoritarismo, o que causa verdadeiras paranóias), como tantos outros foram e muitos jamais foram vistos novamente. A situação é tão crítica (ou parece ser) que quando outra pessoa se aproxima o pavor aumenta, e ele é tão forte que impede a normal convivência entre as pessoas: Cheguei para ele e disse: Ei amigo, você pode me ceder um cigarro?/ Ele disse: Eu dou, mas vá fumar lá pro outro lado/ Dois homens 
fumando juntos pode ser muito arriscado!; situação fácil de se explicar, basta citar como exemplo o fato de que durante o regime militar disciplinas da área de humanidades foram retiradas do currículo escolar e em substituição entraram outras como OSPB $[\mathrm{Xx}$ Xvii], que tinha o intuito de engrandecer e enaltecer os feitos da pátria, e a instituição do ensino técnico, o que afasta as pessoas de um raciocínio mais amplo para enfurná-las em linhas de produção, tudo em nome do crescimento do país. No jogo da censura e do combate aos insatisfeitos, os agentes militares são metaforizados em canibais que têm por objetivo aniquilar, nulificar aqueles que podem trazer problemas, não têm o nobre desejo de adquirir as forças, as características dos oponentes:

Disse: O prato mais caro do melhor banquete é $O$ que se come cabeça de gente

Que pensa e os canibais de cabeça descobrem aqueles que pensam Porque quem pensa, pensa melhor parado.

Mais adiante, um dos personagens revela sua verdadeira, e perigosa, profissão: escritor. É importante salientar que embora o Al-5 tivesse cerceado a atividade criativa da maioria dos artistas, a literatura (pensando em romances) não sofreu tanto quanto a música, o teatro e a imprensa de modo geral:

Desculpe minha pressa, fingindo atrasado

Trabalho em cartório mas sou escritor,

Perdi minha pena nem sei qual foi o mês

Metrô linha 743

As coisas iriam piorar. O que se vê a seguir é uma cena bastante comum nas ruas à época da ditadura, na qual o desrespeito impera e não há explicação nenhuma para as atitudes tomadas, o simples fato de estar inerte em via pública já era sinal de afronta ou de desacato, a degola, assim que constatado o ato ilícito de pensar, é inevitável:

O homem apressado me deixou e saiu voando

Aí eu me encostei num poste e fiquei fumando

Três outros chegaram com pistolas na mão,

Um gritou: Mão na cabeça malandro, se não quiser levar chumbo quente nos cornos

Eu disse: Claro, pois não, mas o que é que eu fiz?

Se é documento eu tenho aqui...

Outro disse: Não interessa, pouco importa, fique aí

Eu quero é saber o que você estava pensando

Eu avalio o preço me baseando no nível mental

Que você anda por aí usando

E aí eu lhe digo o preço que sua cabeça agora está custando

Minha cabeça caída, solta no chão

Eu vi meu corpo sem ela pela primeira e última vez

Metrô linha 743

Como tantos outros que jamais foram encontrados, este tem seu corpo lançado fora como se fosse lixo, como se não merecesse consideração (Jogaram minha cabeça oca no lixo da cozinha/ E eu era agora um cérebro, um cérebro vivo à vinagrete). Os apreciadores de tal iguaria são pessoas distintas, aparentemente de destaque social 
(militares de alta patente talvez). Vendo-se sem saída, encurralado, rende-se, mas não sem antes deixar claro que tal situação não o agrada e uma indagação que muitos certamente faziam:

Fui posto à mesa com mais dois

E eram três pratos raros, e foi o maitre que pôs

Senti horror ao ser comido com desejo por um senhor alinhado

Meu último pedaço, antes de ser engolido ainda pensou grilado:

Quem será este desgraçado dono desta zorra toda?

Além de destacar a falta de comando da situação (como o que ocorre em Anos 80) patenteia que não se preocupam mais em ter cuidado e serem discretos, consideram verdadeiros donos do mundo (como em As aventuras de Raul Seixas na cidade de Thor) e como tal podem fazer o que bem entendem:

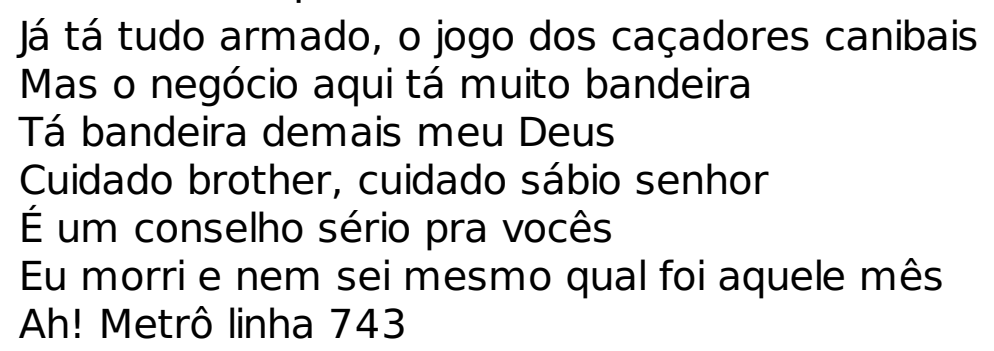

Estas explanações, embora não abarquem tudo o que Seixas disse e pensava sobre o regime militar, dão-nos, ao menos, um panorama de seu posicionamento. É possível ver um autor preocupado com as atitudes arbitrárias dos governantes e ainda mais preocupado com a passividade de muitos cidadãos, Seixas mostra-se sabedor dos perigos que corriam aqueles que, como ele, falavam o que pensavam e mesmo com vigilância cerrada não se calou e tampouco perdeu o humor, a ironia ácida de que usava para satirizar situações absurdas típicas de anos de autoritarismo. "Na conjuntura de repressão dos anos 70, a música popular desses poetas portadores do recado compreendeu talvez mais do que nunca a especificidade da sua força, [...]"[xxviii] e quiçá Seixas tenha sido daqueles que não apenas compreendeu seu papel como fez o que pode para executá-lo.

\section{REFERÊNCIAS}

ALVES, L. Raul Seixas: o sonho da sociedade alternativa. São Paulo: Martin Claret, 1993. ANDRADE, C. D. Antologia poética. Rio de Janeiro: Record, 1993.

AUTRAN, M. O Estado e o músico popular: de marginal a instrumento. In: NOVAES, A. (Org.). Anos 70: ainda sob a tempestade. Rio de Janeiro: Aeroplano; Editora SENAC, 2005. 87-93.

BAHIANA, A. M. Eu em noites de sol. In: PASSOS, S. (Org.). Raul Seixas por ele mesmo. São Paulo: Martin Claret, 2003. 11-39.

. A "linha evolutiva" prossegue - a música dos universitários. In: NOVAES, A. (Org.). Anos 70: ainda sob a tempestade. Rio de Janeiro: Aeroplano; Editora SENAC, 2005. 4152.

COUTO, R. C. Memória viva do regime militar - Brasil: 1964-1985. Rio de Janeiro: Record, 1999. 
HOLLANDA, H. B; Gonçalves, M. A. Cultura e participação nos anos 60. São Paulo: Brasiliense, 1999.

HUTCHEON, L. Poética do pós-modernismo: história, modernismo, ficção. Tradução de Ricardo Cruz. Rio de Janeiro: Imago Ed., 1991. (Série Logoteca).

HYUSSEN, A. Literatura e cultura no contexto global. In: MARQUES, R; VILELA, L. H. Valores: arte, mercado, política. Belo Horizonte: Editora UFMG / ABRALIC, 2002. (Humanitas, 80). 15-35.

LONTRA, H. O. H. Tropicalismo: a explosão e seus estilhaços. In: CYNTRÃO, S. H. (Org.). A forma da festa - Tropicalismo: a explosão e seus estilhaços. Brasília: Editora Universidade de Brasília; São Paulo: Imprensa Oficial do Estado, 2000.

MAURO, A. O último anarquista.In: PASSOS, S. (Org.). Raul Seixas por ele mesmo. São Paulo: Martin Claret, 2003. 41-61.

MOTTA, C. G. Ideologia da cultura brasileira (1933-1974). São Paulo: Ática, 1998. (Ensaios)

PASSOS, S. (Org.). Raul Seixas por ele mesmo. São Paulo: Martin Claret, 2003.

PEREIRA, Carlos Alberto Messeder. Retrato de época: poesia marginal anos 70. Rio de Janeiro: FUNARTE, 1981. 363 p.

PERRONE, C.A. Letras e letras da Música Popular Brasileira. Trad. José Luis Paulo Machado. Rio de Janeiro: Elo, 1988.

SANT'ANNA, A.R. Música popular brasileira e moderna poesia brasileira. Petrópolis: Vozes, 1978.

SANTIAGO, S. O cosmopolitismo do pobre: crítica literária e crítica cultural. Belo Horizonte: Editora UFMG, 2004. 252 p. (Humanitas, 115).

SARTRE, J.P. O que é literatura?.São Paulo: Ática, 1999.

SEIXAS, Raul; Nova, Marcelo. A panela do diabo. Manaus: Warner Music Brasil, 1989. CD.

SEIXAS, Raul. Abre-te sésamo. Manaus: Sony Music, 1980, CD.

. Gita. Manaus: Universal Music, 2003, CD.

. Há dez mil anos atrás. Manaus: Universal Music, 2003, CD.

. Krig-há, bandolo!. Manaus: Universal Music, 2003, CD.

. Mata Virgem. Manaus: Universal Music, 2003, CD.

Metrô linha 743. Manaus: Gala, [198-]. CD.

. Novo Aeon. Manaus: Universal Music, 2003, CD.

. O dia em que a Terra parou. Manaus: Warner Music Brasil, [199-]. CD.

SOUZA, E.M. Crítica cult. Belo Horizonte: Editora UFMG, 2002. 177 p. (Humanitas, 79).

VENTURA, Z.; GASPARI, E.; HOLLANDA, H.B. Cultura em trânsito: da repressão à abertura. Rio de Janeiro: Aeroplano Editora, 2000.

VILARINO, R. C.MPB em movimento: música, festivais e censura. São Paulo: Olho d'água, 1999.

WISNIK, J. M. O minuto e o milênio ou por favor, professor, uma década de cada vez. In: NOVAES, A. Anos 70: ainda sob a tempestade. Rio de Janeiro: Aeroplano; Editora SENAC, 2005. 25

\footnotetext{
[i] ADELMAN. O reencantamento do político: interpretações da contracultura.

[ii] SANT'ANNA. Música popular brasileira e moderna poesia brasileira, p.245.

[iii] ALMEIDA JÚNIOR. A contra cultura ontem e hoje.

[iv] ADELMAN. O reencantamento do político: interpretações da contracultura.

[V] MOTA. Ideologia da cultura brasileira (1933 - 1974), p. 265.

[vil No ano de 1960 houve o troféu Noel Rosa, concedido a Newton Mendonça, por isso a emissora intitular seu festival com o referido numeral.

[vii] MOTA. Ideologia da cultura brasileira (1933 - 1974), p. 265.

[viii] PERRONE. Letras e letras da Música Popular Brasileira, p. 46.

[ix] VILARINO. MPB em movimento: música, festivais e censura, p. 79.
} 
$\underline{[x]}$ BAHIANA. A "linha evolutiva" prossegue - a música dos universitários, p. 43.

[xil] VENTURA. Cultura em trânsito, p. 59.

[xii] Um trecho desta entrevista pode ser encontrado e mo Estado e o músico popular: de marginal a instrumento, de Margarida Autran.

[xiii] AUTRAN. O Estado e o músico popular: de marginal a instrumento, p. 88.

[xiv] VILARINO. MPB em movimento: música, festivais e censura, p. 85.

$[\mathrm{XV}]$ ALVES. Raul Seixas: o sonho da sociedade alternativa, p. 103.

[Xvi] VILARINO. MPB em movimento: música, festivais e censura, p. 18

[xvii] SANT'ANNA. Música popular brasileira e moderna poesia brasileira, p.223.

[xviii] VILARINO. MPB em movimento: música, festivais e censura, p. 24.

$[\mathrm{xix]}$ SANT'ANNA. Música popular brasileira e moderna poesia brasileira, p.226.

$\underline{[x]}$ Depoimento de Caetano Veloso está em Cultura e participação nos anos 60 , de Heloisa B. de Hollanda e Marcos A. Gonçalves, na página 51.

[xxi] SOUZA. Crítica cult, p. 155.

[xxii] Cf. depoimentos de Veloso e Rocha concedidos à Hollanda e Messeder em Cultura em trânsito, p. 146168.

[Xxiii] RAUL SEIXAS. As aventuras de Raul Seixas na cidade de Thor. In: Gita. Manaus: Sony Music, 2003. CD. 03,3 '43.

[Xxiv] LONTRA. Tropicalismo: a explosão e seus estilhaços, p. 40.

[XXV] “Os CPCS se espalharam por todo o país atraindo jovens e intelectuais que desenvolviam uma atividade conscientizadora junto às classes populares. Defendiam a arte revolucionária, instrumento de revolução social. Trabalhavam em contato direto com as massas. Encenavam peças em portas de fábricas, favelas e sindicatos. Publicavam livros de poesia a preços populares e realizavam filmes autofinanciados." (In. ALVES, L. Raul Seixas: o sonho da sociedade alternativa, p. 15.)

[XXVi] HUYSSEN. Literatura e cultura no contexto global, p. 29.

[XXvii] HUTCHEON. Poética do pós-modernismo, p. 69.

[xxviii] Cf. Culturas híbridas.

$[$ [xix] HUTCHEON. Poética do pós-modernismo, p. 29.

$[\mathrm{xxx}]$ Sobre este assunto é indispensável a leitura de Retrato de época, de Carlos Alberto Messeder Pereira.

[xxxi] PEREIRA. Retrato de época, p. 39.

[xxxii] RAUL SEIXAS; PAULO COELHO. Eu também vou reclamar. In: Há dez mil anos atrás. Manaus: Sony Music, 2003. CD. 06, 3'20.

[XXXiii] MARCELO NOVA; RAUL SEIXAS. Rock'n'roll. In: A panela do diabo. Manaus: Warner Music Brasil, 1989. CD. 02, 5'20.

[XXXiv] HUYSSEN. Literatura e cultura no contexto global. p. 27.

$[x x x y]$ RAUL SEIXAS; PAULO COELHO. Rock do diabo. In: Novo Aeon. Manaus: Sony Music, 2003. CD. 02, 2'10.

[XXXVi] É interessante ressaltar que surgiram à época vários grupos culturais importantes, como: Vida de Artista, Nuvem Cigana, Folha de Rosto. Não é possível deixar de mencionar O Pasquim, que contava com Ziraldo, Millôr Fernandes, Jaguar, Henfil, que com muito humor criticavam a situação política e econômica do país.

[XXXVii] PEREIRA. Retrato de época, p. 149.

[XXXviii] RAUL SEIXAS; PAULO COELHO. Super-heróis. In: Gita. Manaus: Sony Music, 2003. CD. 01, 3'12.

$[x x x i x]$ RAUL SEIXAS. É fim do mês. In: Novo Aeon. Manaus: Sony Music, 2003. CD. 10, 2'58.

[XI] MAURO. O último anarquista. p. 46.

[xli] SARTRE. O que é literatura?, p. 65.

[xliil WISNIK. O minuto e o milênio ou por favor, professor, uma década de cada vez, p. 30.

[xliii]

[xliv] Tomo esta expressão emprestada de José Miguel Wisnik em seu texto O minuto e o milênio ou por favor, professor, uma década de cada vez.

[xlv] AUTRAN. O Estado e o músico popular: de marginal a instrumento, p. 87.

[xlvil No álbum original de 1975 o nome da canção aparece grafado Para Nóia. Esse fato passa a impressão de a música ser oferecida a Nóia, ou seja, ao medo. Hoje essa expressão é usada por alguns jovens para nomear as sensações causadas por alguns narcóticos. Uso, no entanto, a grafia de que disponho.

[xlviil MAURO. O último anarquista, p. 48.

[xlviii] RAUL SEIXAS. A mosca. In: Krig-há, bandolo!. Manaus: Sony Music, 2003. CD. 02, 3'56.

[xlix] ANDRADE. Antologia poética, p.196.

Ill SANTIAGO, O cosmopolitismo do pobre, p. 137.

[li] Serviço Nacional de Informações. 
[lii] Departamento de Ordem Política e Social.

[liii] RAUL SEIXAS; PAULO COELHO. Rockixe. In: Krig-há, bandolo!. Manaus: Sony Music, 2003. CD. 09, 3’43.

[liv] Para compreender o cenário político da época, é fundamental a leitura de Memória viva do regime militar - Brasil: 1964-1985, de Ronaldo Costa Couto. É desta obra que foram extraídas as informações e dados referenciados nesta parte do trabalho.

[lv] MAURO. O último anarquista, p. 49.

[lvi] RAUL SEIXAS. As aventuras de Raul Seixas na cidade de Thor. In: Gita. Manaus: Sony Music, 2003. CD. 03, 3'43.

[lvii] RAUL SEIXAS; PAULO COELHO. Sociedade alternativa. In: Gita. Manaus: Sony Music, 2003. CD. 12, 4'46. [lviii] MAURO. O último anarquista, p. 50.

[lix] Há quem diga que Seixas foi torturado e ameaçado pelos militares, outros, que houve apenas uma conversa. Como o que importa para este trabalho são as relações que ele manteve com o todo da época, não tecerei comentários acerca de algo hipotético, isso fica para os biógrafos.

$[\mathrm{lx}]$ BAHIANA. Eu em noites de sol, p. 31.

[lxi] COUTO. Memória viva do regime militar - Brasil: 1964-1985, p. 365.

[Ixii] RAUL SEIXAS. Paranóia. In: Novo Aeon. Manaus: Sony Music, 2003. CD. 08, 3’50.

[lxiii] PASSOS. Raul Seixas por ele mesmo, p. 33.

[lxiv] AUTRAN. O Estado e o músico popular: de marginal a instrumento, p. 88.

$[\mathrm{Ixv}]$ COUTO. Memória viva do regime militar - Brasil: 1964-1985, p. 366.

[lxvi] p. 366.

[lxvii] , p. 367.

[Ixviii] RAUL SEIXAS; CLÁUDIO ROBERTO. Sapato 36. In: O dia em que a terra parou. Manaus: Warner Music Brasil, [199-]. CD. 03, 4'25.

[lXix] RAUL SEIXAS; PAULO COELHO. Conserve seu medo. In: Mata virgem. Manaus: Warner Music Brasil, [199-]. CD. 05, 1'44.

$[\mid \mathrm{xx}]$ Cf. COUTO. Memória viva do regime militar - Brasil: 1964-1985, p. 367.

[Ixxi] RAUL SEIXAS; CLÁUDIO ROBERTO. Abre-te sésamo. In: Abre-te sésamo. Manaus: Sony Music, 1980. CD. 01,2 '33.

[lxxii] RAUL SEIXAS; DEDÉ CAIANO. Anos 80. In: Abre-te sésamo. In: Abre-te sésamo. Manaus: Sony Music, 1980. CD. 03, 2'49.

[lxxiii] COUTO. Memória viva do regime militar - Brasil: 1964-1985, p. 369.

[lxxiv]

$[\mathrm{IxxV}]$ p. 369.

p. 371

[lxxvi] RAUL SEIXAS. Metrô Linha 743. In: Metrô Linha 743. Manaus: Gala, [198-]. CD. 01, 2’45.

[lxxvii] Organização Social e Política Brasileira.

[lxxviii] WISNIK. O minuto e o milênio ou por favor, professor, uma década de cada vez, p. 26. 